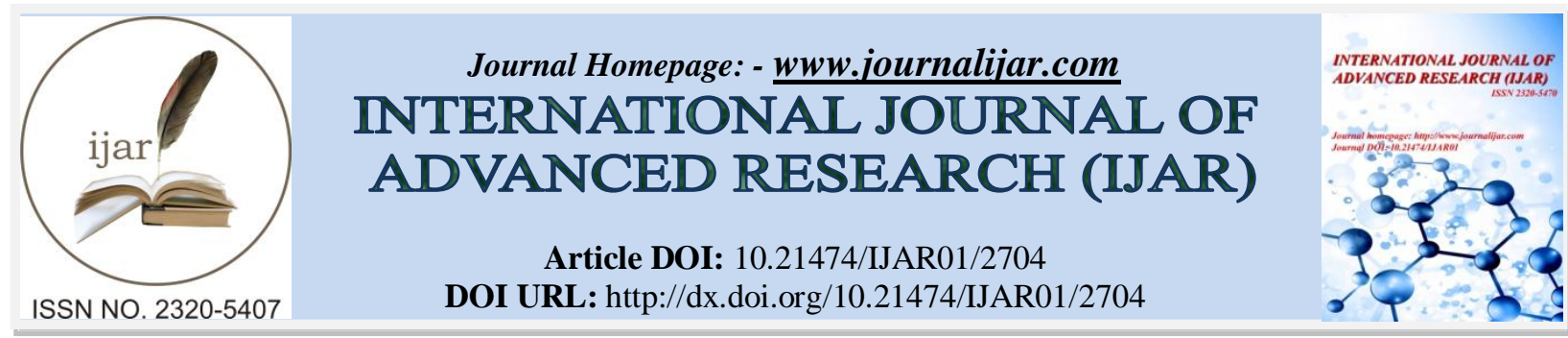

RESEARCH ARTICLE

\title{
THE EFFECT OF ETHNICITY ON COLLECTIVIST FAMILIES' MEAL SOCIAL INTERACTION BEHAVIOUR IN SIERRA LEONE.
}

\author{
Dr. Sheku Kakay.
}

\section{Manuscript Info}

Manuscript History

Received: 31 October 2016

Final Accepted: 01 December 2016

Published: December 2016

Key words:-

Ethnicity, family/consumer behaviour, social interaction, collectivism, gender groups.

\section{Abstract}

Ethnicity has been touted to have a significant influence on Sierra Leonean families' meal consumption behaviour. It is used to define the social grouping of individuals as it is aligned with the type of language they speak, their cultural beliefs, the region or community they come from and most notably the assumptions they espoused at the dinner table. These factors are symbolic in defining the character of individuals at mealtimes, but it significance vary from family to family based on their ethnic orientation and the degree of acculturation experienced by them. This paper evaluates the effect ethnicity has on the collectivist behaviour of Christian and Muslim families' when they interact socially at mealtimes. This is emblematic of the fact that the cultural behaviour of families is never sacrosanct and inflexible, but changes from time to time based on their level of exposition either to a new environment or a new social group they interact/come in contact with. Consequently, this paper highlights the degree of influence ethnicity has on the behaviour of Christian and Muslim families (husband and wife) at mealtimes and draw attention to its significance as influencer of collectivism, particularly in relation to its impact on the social interactionbetween similar and dissimilar gender groups. The authors critically reviewed the degree of influence ethnicity has on families' meal consumption behaviour and presented a comparative analytical summary of how gender affect the meal behaviours of different gender and religious groups.

Copy Right, IJAR, 2016,. All rights reserved.

\section{Introduction:-}

Sierra Leone is a multi-ethnic country with a very peculiar and complicated history. It has a diversity of kingdoms and traditional practices espoused by different ethnic groups, including: Mende, Temne, Limba and Fulani (Akinsulure-Smith and Smith, 2014; Robinson, 2013; and Taylor, 2014). There are over 18 different ethnic-cultural groups in Sierra Leone, mostly based on ethnicity, language, religion and traditional beliefs. Abraham et al (2013) and Taylor (2014) supported this argument by proclaiming that there are between fifteen and twenty ethnic groups in Sierra Leone, depending on one's linguistic tendency to "lump" or "split" groups of people speaking different dialects. Albeit the distinctness of each of these ethnic groups, the majority of them are incline to speak Creole. However, it is important to realise that irrespective of the collectivistic culture of Sierra Leonean families, the meal consumption and social interaction behaviour of the various ethnic groups differs significantly. Cohen (2013) and Million (2013) also mentioned that sometimes villages, and sometimes families within villages, will have specific 
taboos or proscriptions against eating certain foods. Abraham et al (2013) claimed that these are usually attributed to a law handed down from ancestors or perhaps the founder of the village. Therefore, one can argue that the food consumption behaviour that is acceptable in certain areas by specific ethnic group may be regarded as taboo by others. What a certain ethnic group sees as a social way of life is seen as a taboo by others. Millan and Reynolds (2010); Parker and Grinter (2014); and Wien and Olsen (2014) suggested that there is limited knowledge of the implications of the interplay between ethnicity and family meal social interaction patterns. Fitzsimmons and Stamper (2014); and Muk et al (2014) noted that the interdependent self-concepts reflect internalisation of these ethnic values, which may therefore be a better predictor of consumption behaviour.

In Sierra Leone, individualism is also eminent among the ethnic group referred to as creoles, who are freed slaves from the United States and/or the United Kingdom. They have more individualistic and British or American thinking than the average Sierra Leonean from other ethnic groups. This view was also supported by Glennerster et al (2013); Little (2013); and McFerson (2013), who reiterated that creoles practiced more independence than the average Sierra Leonean, and concludes by stating that they are largely influenced by British and American cultures. In summary, upper income households, creoles and academics are more inclined to practice individualism, because of either their educational attainment or the influence of places they have travelled/visited and/or lived. In such cases, they are likely to imbibe the individualistic culture of places lived/visited. However, even within these groupings, irrespective of their social standings, some are still influenced bycollectivistic ethnic tendencies.

This paper presents a critical analysis of the influence of ethnicity on families' meal social interaction behaviour and chronicle arguments responsible for the display of such behaviour. Invariably, the paper highlighted the degree of influence ethnic factors such as: tribe, region of origin, cultural beliefs and assumptions have on families' meal social interaction behaviour and how that symbolically influenced the degree of acculturation experienced by individuals when the move to either new social settings or interact with people from different ethnic backgrounds.

\section{Theoretical underpinning:- Analysing the concept of culture:-}

Scutte and Ciarlante (1998) stated that the interpretation of culture is too simplistic and parochial as there are many deep-rooted issues that affect people's lives and ways of doing things that are not visible and many times are taken for granted. In his cultural research, Utami (2014) supported this view by identifying a third element (assumption) as the most critical issue that is neglected by many researchers. He noted that the behavioural practices are only a tip of the iceberg, emphasising that to gain a better understanding of the cultural argument, it is vital to venture below the surface to examine not only society's declared values and beliefs, but also the basic assumptions taken for granted by that society's members. Hence, the categorisation of the cultural elements into three different levels: 1. Behavioural practices, 2. Values, beliefs, preferences and norms, and 3. Basic assumptions (Schutte and Ciarlante, 1998; Marshall et al, 2011; and Utami, 2014). These three different levels are comprehensively discussed and depicted in Figure 1 below. 
Figure 1:- The three levels of culture.

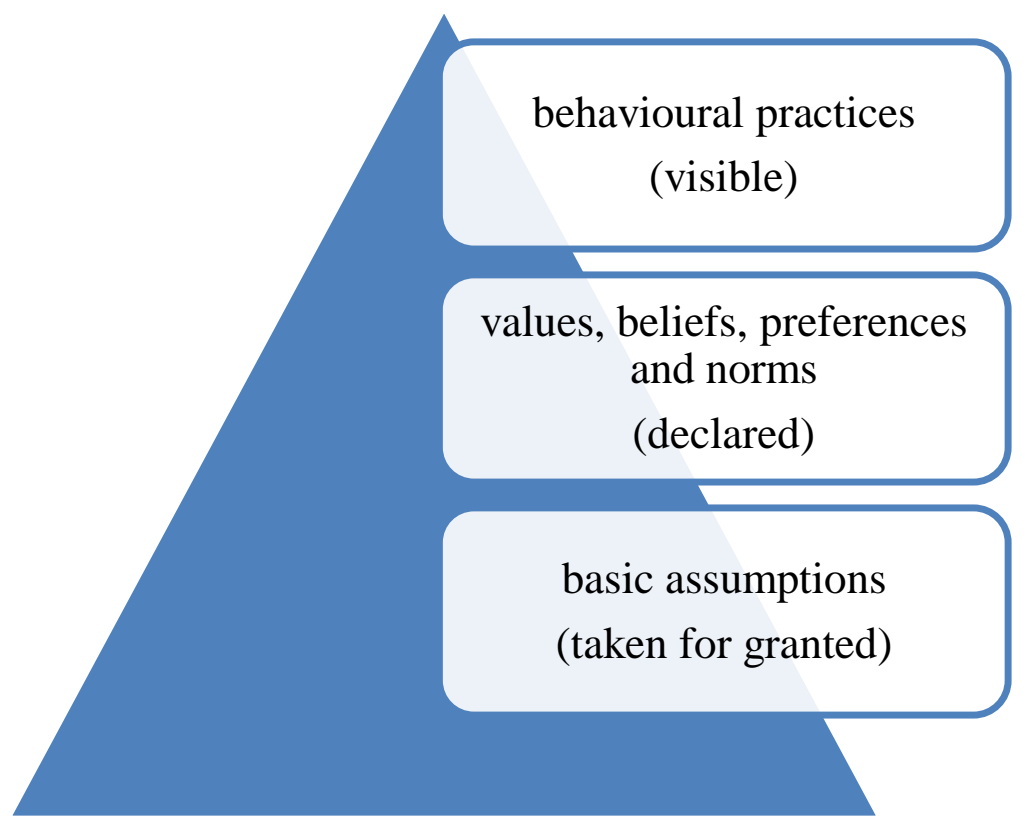

Source: Adapted from Schutte and Ciarlante, 1998; p. 7

Behavioural practices across cultures or societies vary from one to another and are mostly defined by the specific cultural settings to which people belong, which is largely visible to the public. De Mooij (2013) affirmed this view by positing that the way people behave varies from culture to culture, which he noted could lead to considerable misunderstanding between members of different societies. Hansen (2013) gave an example of the behaviour of Sioux Indians of South Dakota, who regard answering a question in the presence of the ignorant others as incorrect. Proclaiming that such behaviour would be regarded by others as boastful and arrogant, and signals undermining the confidence of others by shaming them. He identified an additional trait of the Sioux Indians, who consider it offensive to provide a wrong answer to a question, except when absolutely sure of the correct answers. He also suggested that when the Sioux Indian children were faced with a white American teacher, who was unaware of their culture in a classroom, the teacher may interpret the Sioux Indians children's behaviour as a reflection of ignorance, stupidity or hostility.

Many cultural assumptions are deep-rooted beliefs that generate basic values, which guide our daily behaviour indirectly and are mostly subconscious as they shape our conduct and interaction with others, but are usually taken for granted. This view was buttressed by De Mooij (2013) that culture determines how members of society think and feel - which direct their actions and define their outlook on life. He emphasised how members of a given society usually take their culture for granted because it has become so much part of them that they are often unaware of its existence. Nash (2014) gave an example of two individuals, one from South America and the other from North America, who were conversing in a hall 40 feet long. He emphasised that the two individuals began at one end of the hall and finished at the other end with the North American steadily retreating, while the South American relentless advancing with each trying to establish the accustomed communication distance defined by his culture. He pointed out that the North American was uneasy when his South American counterpart comes too close for comfort, whereas the South American was uncomfortable conversing at a distance. This shows individuals cannot clearly define their cultures until they are confronted with a meeting like this, which reveals the pervasive nature of culturally determined behaviour. It is apparent, however, that Nash's example despite its element of truth, it is blurred by perception as it is largely based on subjective view with no empirical data to support the claim as the United States is a melting pot consisting of people from various continents such as Asia, Africa, Europe and even South America, who may have similar cultural orientation with the South American and therefore more comfortable with the South American. 
Another useful analysis of culture in several academic discussions is the one developed by Hofstede (2001); and Zakaria (2014), who suggested an "onion" model to describe the different layers and features of culture, proclaiming that culture in itself is a difficult topic to research due to its lack of measureability both objectively and subjectively as it is difficult to unravel what is embedded in human behaviours, whether overt or tacit. The model illustrates the different layers of culture, with the degree of complexity increasing as one move from the outer layer to the core of the inner layer. Hofstede (2001); and Zakaria (2014) noted that the outer layer depicts what people own is manifested in artefacts or material objects; and that the middle layer depicts what people think as reflected in their beliefs, attitudes, and values; and that the innermost layer or core depicts what people do as the key determinant of their normative patterns of behaviours and assumptions.

Figure 2:- The onion diagram: The manifestation of culture at different levels

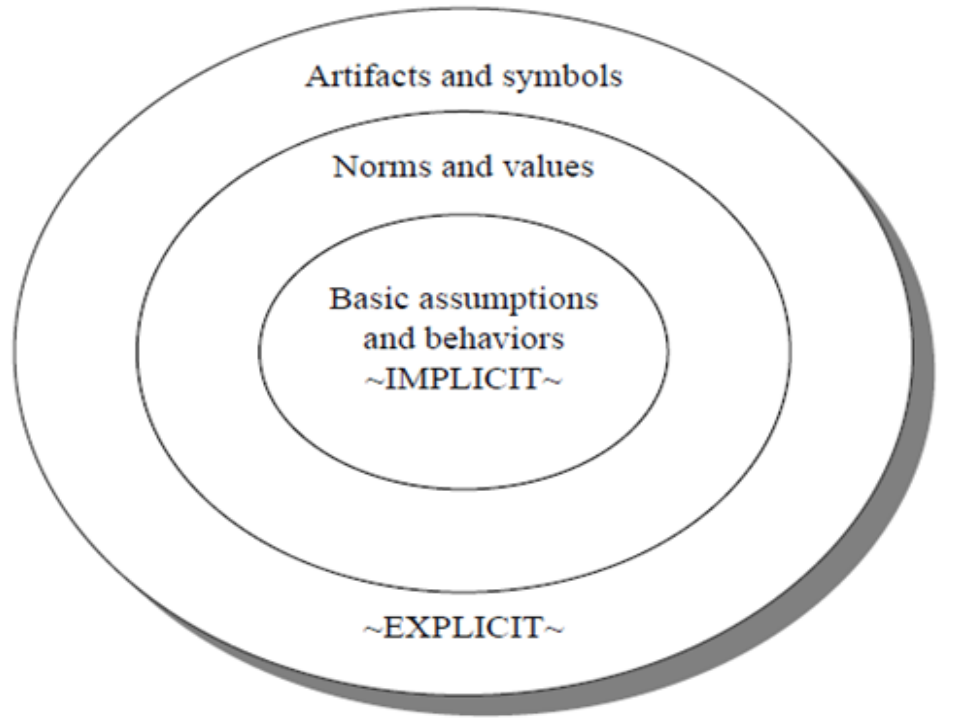

Source: Adapted from Hofstede (2001); Zakaria (2014)

Renteln (2013) noted that norms are prescriptive principles to which members of a culture increasingly subscribe to. $\mathrm{He}$ emphasised that the underlying premise of cultural value's is that people from different cultures differ normatively in their value orientations, which may ultimately cause differences in their overt or covert behaviours most of the time. Brown (2014) suggested that values are "a broad tendency to prefer certain states of affairs over others; while De Mooij (2013) elaborately defined value as desirable states, objects, goals, or behaviours, transcending specific situations and applied as normative standards to judge and to choose among alternative modes of behaviour. Jirachiefpattana (2014) supported this assertion and stressed that values are in large part culturally driven. From the propositions, it is justified to say cultural values drive a person's beliefs, attitudes, and behaviours.

The analysis provided by Hofstede (2001); and Zakaria (2014) about the innermost layer provides an in-depth understanding and clarity into the issues responsible for the differences and similarities of values between cultures and even within the same culture. Cawelti (2014) reiterated that basic assumptions are the implicit or hidden aspects of culture, which spring from needs at the core of human existence. Cooper and Cefai (2013) emphasised that basic assumptions are behavioural rules that regulate actions and guide people to practical ways of managing their relationships with their environment (external adaptation); as well as with other people (internal integration). Cooper and Cefai (2013) pointed out that in the core layer, behaviours often have unconscious motivations because basic assumptions are not articulated and are taken for granted. Other scholars contributed additional models to the cultural argument: for example, Hall (1976) was primarily concerned about time, space, and context; Hofstede (2001) focused on work-related values; whilst Trompenaars (1993) centres his argument on business values. It is evident that Hofstede's basic assumptions enhance comprehension of the complications of culture, which is vital for families who need to cooperate and collaborate during their social interaction at meal times as a unit to find solutions to their shared problems. 


\section{The effect of acculturation on culture:-}

Lopez-Class et al (2011); and Schwartz et al (2010) defined acculturation as a multidimensional process that includes the identification, values, and practices that change through: contact with a new culture; or that are shaped through growing up in another family and/or community; or by immigrating to another country. Kuo (2014) defined acculturation as the "phenomena which results when groups of individuals having different cultures come into continuous first-hand contact, with subsequent changes in the original cultural patterns of either or both groups. The use of such a notion of acculturation considers the heritage and receptiveness of cultures separately (Des Rosiers et al., 2013). Marsiglia(2013) brought a new dimension to the definition by looking at acculturation as the orientations towards heritage and receiving cultural contexts and practices among immigrants and their descendants. In comparison, Allen et al. (2014) viewed the acculturation construct in terms of cultural behaviours, for example, language use, food preferences, and family and friend relationship styles. Schwartz et al. (2013) pointed out that irrespective of the fact that acculturation includes cultural values and identifications as well as practices, it is important to consider other relevant dimensions such as ethnic identity. Schwartz et al (2013); and Umaña-Taylor et al. (2014) reiterated that ethnic identity is the subjective experience of heritage-culture retention; and the extent to which individuals view their ethnic identity group positively. However, Umaña-Taylor et al. (2014) noted that ethnic identity is an aspect of the entire acculturation process that can be distinguished from other aspects by virtue of its focus on subjective feelings about one's ethnicity. Schwartz et al (2010) specifically referenced the acculturation orientations of Hispanic and American cultural practices and concluded that heterogeneity in acculturation orientations among Hispanic emerging adults was related to a number of cultural variables such as acculturative stress, collectivist values, familism, and discrimination.

Ho and Johnson (2013) argued that unless the influence of acculturation is measured, inappropriate conclusions may be drawn regarding cultural variation. Sauer (2014) also pointed to the importance of understanding an individual's level of acculturation, or the process of change in people's activities, thinking patterns, values, and self-identification before acculturation can be properly discerned. Han and Pong (2015) suggested this is important in order to measure the psychological, behavioural, and attitudinal changes that occur when individuals and groups from different cultures come into continuous contact with each other. To increase the level of clarity on a complex issue like culture, Rebhun (2014) proposed two models of acculturation - The linear model assumes that as individuals develop strong mainstream ties, their ethnic ties are weakened, which might weaken ethnic identity; and the twodimensional model, on the other hand, where they do not assume such a trade-off, but pointed out that individuals can have strong or weak identifications with their ethnic culture and with the mainstream culture, and that the influence of acculturation may vary between individuals and may even have a differential effect on their values, beliefs, assumptions and behaviours (Fischer-Neumann, 2014). The models proposed by Ho and Johnson (2013); and Sauer (2014) that acculturation cannot be firmly ascertained unless it is measured, may have some elements of truth, as Dinnerstein and Reimers (2013) suggested that people change their ethnicity at all times either as a result of immigration, emigration or as a result of the influence of being brought up in a certain society. As a result, Tal (2013) argued that due to acculturation, people's ethnicity is never stagnant and is dependent on the sternness, degree of flexibility and values of the individual, family or group.

\section{The effect of Ethnicity on culture:-}

Brice (2012); and Blaydes and Grimmer (2013) defined ethnicity as the sets of values, beliefs and norms which are largely shared within ethnic groups with defined boundaries, and that national culture is that culture which is more or less bounded by a country's political borders. Vargas and Kemmelmeier (2013) stated that it is commonly assumed that culture is always ethnic based and collectivism encourages tight ties between individuals, who are members of in-groups. A number of theorists have undoubtedly found evidence that values, beliefs and norms result in behavioural differences between cultures (Halpern, 2013; Morn et al., 2014; Serenari et al, 2013). Ethnic groups go through a process of cultural and psychological change when exposed to a different culture (Kuczynski and Knafo, 2013; Lorenzo-Blanco and Cortina, 2013), which may lead to increases in individual differences within the ethnic groups (as individuals assimilate at different paces). Moran et al. (2014) found that ethnically diverse groups with people from collectivist cultural traditions tended to be more cooperative and largely influenced by their immediate family members. The notion that ethnic groups go through cultural and psychological process is too simplistic and parochial as some people are so ethnocentric that even after migrating to other places they still keep their cultural values and become very resistant to change, but rather will work to influence the new culture to their advantage (Inkeles, 2013). 
Sauer (2014) suggests that the complex construct of ethnicity, as one important factor of self-identity, needs to be broken down into the different variables of which it is comprised, and in his study of ethnic groups, he recommended that researchers should measure the specific cultural values of an ethnic group in order to determine the relevant differences, assess differences within the group, and evaluate how the values inherent in them can predict behaviours or attitudes. Hence, he suggested that it is imperative to understand why societies or communities differ ethnically. Researchers and theorists should measure individual family cultural values rather than characterising ethnicity based on generic assumptions as measuring individual values provides not only a reflection of the differences between groups of families, but also the differences that exists between the families of the same ethnic group (Gaines, 2014; Kozhevnikov et al, 2014). As this is the only way to measure and identify the differences and similarities between one ethnic group/family and the other with a modicum of justification.

Smith et al (2013); and Walls and Triandis (2014) suggests that the values of collectivism or the extent to which interdependence is favoured in a culture, appears to be one of the main fundamentals required for distinguishing ethnic groups. Collectivist societies stress group solidarity, duties and obligations, stable friendships, and particularism (Lu et al, 2013; Misztal, 2013). Families with strong collectivistic values tend to favour group solidarity, obligations, security, obedience, duty, and personalized relationships (Alesina and Giuliano, 2013; Trovão, 2014). In addition, Häuberer and Tatarko (2014) noted that individuals with a strong collectivistic orientation tend to belong to a select few in-groups such as families and friendship circles. Due to the stability of these in-groups, collectivists generally discriminate against out-group members and favour in-group members (Hildebrand et al., 2013). Chang (2014) in his study of Hispanics in the USA found out that Hispanics are characterised as having collectivist values with the family perceived as the primary in-group. Guerrero and Posthuma (2014) concluded that Hispanics were more competitive than Anglo-Americans when working in a group in which the majority was from another ethnicity (i.e., a group potentially perceived as an out-group). Earlier studies conducted by Aboud and Spears (2013); and Goar et al (2013) found a similar outcome and stated that ethnically diverse groups were more cooperative than the Anglo groups (in a prisoner's dilemma that simulates a work environment). They found in their studies that all groups responded in a predominantly competitive manner, and suggested that this could be due to the level of acculturation of the minorities within the ethnically diverse groups. Though the impact of acculturation on specific ethnic group has not been studied extensively, a number of researchers such as Cohen (2013); and Bornstein and Bradley (2014), agree that it is an important variable that must be considered when studying ethnic groups and their values.

Stayman and Despande (1989) used an empirical study to illustrate that ethnicity may even be situation dependent, and defined it as "situational ethnicity". They justified this because bicultural members of minority cultural groups may respond using norm sets from two different cultural backgrounds and that contextual cues may dictate which norm set is operative in a given situation. As such, that particular context may determine which of a person's communal identities or loyalties are appropriate at a point in time. Okamura et al (2010); and Fiske and Taylor (2013) added that the cognitive aspect of situational ethnicity is critical and that individuals' perceptions and interpretations of the signs and symbols of a situation determine their behavioural options. It is now generally accepted that ethnicity is best understood as a complex multidimensional construct rather than a categorical variable based on self-described group membership (Vargas, 2013; Bartkowski and Shah, 2014; Schlenker, 2014). These views that suggest ethnicity is situation dependent, is confusing and self-defeating as people's cultural orientation are difficult to change overnight, though it is not uncommon for people to acculturate, but still import part of their old culture and use it as a mixture with the new unknowingly (Diller, 2014).

Zeiders et al (2013); and Peštek and Činjarevic (2014) noted that certain components/dimensions of ethnicity are of particular relevance in explaining its impacts, including but are not limited to, ethnic identity, culture, the experience of discrimination and adherence to the group. Peštek and Činjarevic (2014) stressed that in most instances, the effects that appear to be related to differences in ethnic group membership are best explained by variation across one of these component variables. Biziouras (2014); Oh et al (2014) in their study of Latinos discovered that, they report significantly more auditory hallucinations than European Americans, but however warned that these differences of ethnicity are primarily attributable to religious differences, and emphasised that participation in religious activities is a cultural variable that is a subcomponent of ethnic identity. Oh et al (2014) noted that once the effects of religion were controlled, there were no differences between Latino and European American reports of auditory hallucinations. Thus, the use of a multidimensional understanding of ethnicity makes it possible to identify the specific mechanism through which ethnicity operates on psychologically important outcomes. The exploration of the relations among key components of ethnicity has recently become a focus of attention (for example, Back, 2013; 
Neal, 2013; Rampton, 2014). Hence, undertaken a study to unravel the different components of ethnicity that influences families' meal social interaction behaviour is important.

Activities that have been used to study the effect of ethnicity on culture over the years include: language; choice of friendship; religious affiliation and practice; political ideology and activity; region of origin; participation in structured ethnic social groups; and miscellaneous ethnic/cultural activities and attitudes (Rampton, 2014). The exact nature and relative importance of each of the above activities will vary from one group to the other. For example, Qin et al. (2014) pointed out that the role of ethnic language proficiency; in-group peer social interaction and parental cultural maintenance are predictors of ethnic identity in adolescents. In addition, Gaertner and Dovidio (2014); and Miller and Ali (2014) noted that the components of ethnic identity may combine differently for different individuals and evidenced that individuals may identify strongly with their ethnic group, feel a strong sense of belonging, have positive attitudes toward the group, and yet fail to share in any behaviours or attitudes that differentiate this group from others. Gaertner and Dovidio (2014) reiterated that individuals who fit into this category are thought to have symbolic ethnicity or ethnic loyalty and that the particular way these dimensions of ethnic identity combine for different individuals may influence the type of ethnicity. Bejanyan et al. (2014) and Devos and Vu (2014) stated that ethnic traditionalists are held together primarily by emotional ties as a result of long history and that their children are socialised to internalise these cultural values. They emphasised that these groups are not interested in social and economic interests, but are concerned about the maintenance of their culture, and identify strongly with the ethnic group to which they belong. The pessimism expressed by the theorists in terms of behavioural or attitudinal difference shared by people of similar ethnic group has some element of truth, especially if the orientation and upbringing of the individual is different from those of the others, but it is important to reiterate that most people are emotionally bonded as a result of blood ties and history, and the children are socially internalised to uphold the same cultural values.

\section{Individualism/collectivism:-}

Variation across individualist and collectivist cultures has been recognised as one that portrays hierarchical relationship leading to horizontal (equality) and vertical (hierarchy) dimensions of individualism and collectivism (Usunier and Lee, 2009; Parker and Grinter, 2014; Schommer-Aikins and Easter, 2014). Abbott (2014) stated that a rigid hierarchical social structure leads naturally to a heightened sensitivity towards status. In a previous study, Reykowski (2012) distinguished the individualistic value from the collectivist by referencing authority as originating from a relationship between individuals either from common agreement or from differences in strength, while collectivists view power as an attribute of a group, and the group's will can be expressed either by majority vote, by opinion of elders or by a charismatic leader. It is apparent that distinguishing individualism and collectivism using vertical and horizontal relationship in a group or family structure is much complex than professed by the theorists as there are several underlying factors such as group dynamic, degree of closeness, contribution to the in-group, etc. that needs to be considered before one can justify the claims. However, it is important to note that authority in most African families is based on hierarchical structures, which revolves around the head of the family as the decisionmaker.

In his study, Chen (2013) distinguished the two types of individualism, by claiming that in a vertical individualist societies, people are inclined to separate themselves from others; while in horizontal individualist societies, they express uniqueness and self-reliance. Contrarily, Schapper (2013) professed that individualistic societies lack not only horizontal, but also vertical integration; and stressed that adolescent children leave the homes of their parents and do not necessarily maintain contact after their departure with the rest of the family and the memories of deceased ancestors quickly fade away. In his review of collectivist societies, Yuan (2013) distinguished between vertical and horizontal collectivism by defining the former as one that enhances cohesion and status of in-group and promotes compliance with authorities and defined the later as more socialistic and interdependent. This view supports a previous study conducted by Hofstede (2003, p. 231) that "collectivist cultures usually have ways of creating family-like ties with persons who are not biological relatives, but who are socially integrated into one's ingroup", and referenced Latin America as an institution of 'compadres and comadres', who treat individuals as relatives even though they are not. This sentiment was also expressed by Yamaguchi (2013), who noted that in the Japanese society, social relations are facilitated by vertical relationships that help to avoid uncertainty and riskiness in dealing with others. The manifestations of the theorists (Hofstede, 2003; Yamaguchi, 2013; and Yuan, 2013) can be reflective of the Sierra Leonean society, where socialistic tendencies and interdependency is prominent in most families, who sometimes accommodate non-blood relations as part of their in-groups (Letseka, 2013), and equally fend and provide for their needs just as those of their biological relations. 
In collectivist cultures, individual's identification with the collective goal of the group typifies the significance of belongingness (Greenfield and Quiroz, 2013; Smith et al, 2013; Peterka-Benton and Benton, 2014). As a result, priority is given to the success of the group as a whole (Greenfield and Quiroz, 2013). Zhang and Zhao (2013) emphasised that the primary concern of the majority of Chinese was how to protect and enhance their private kinship interests. Black (2013) supported that argument by stating that Chinese learn to "swallow anger" and to tolerate the intolerable because they do not see how they can live outside their family of origin or marriage. Black concluded his argument by referencing Chinese parents' punishment of intolerable behaviour with reprimands, striking and isolation. Beh and Kennan (2013); Herzfeld(2014); and Kwek (2014) also referenced China as a country where a number of cultural norms have been established among groups to achieve social harmony and guide day to day behaviour. Beh and Kennan (2013) argued that the principle of ' $l i$ ' (rite) guides the individual in his/her social interactions with others by spelling out the proper way to behave in various social settings and toward various individuals with whom he/she has interpersonal relationships. Herzfeld (2014) emphasised that the principle of ' $i$ ' requires the individual to behave according to his desires or for self-centred reasons, but to follow what is prescribed by ritual, constantly monitoring his/her own behaviour to ensure that it is socially acceptable to the collective (group). Black's argument of punishing individuals to correct the behaviour of individuals and the persistent monitoring of group behaviours, especially those of children mirrors what is obtained in the social interactions of most families in Sierra Leone.

\section{The symbolism of family meal social interaction behavior:-}

A number of sociological and social anthropological studies of food have characteristically focused on food cultures and the collective character of family social intercourse eating patterns among various social groups (Beattie, 2013; Kuper, 2013; and Parsons, 2013). Quarmby and Dagkas (2013); Baker and Gibson (2014); and Pound and Campbell (2014) stated that in contrast to behavioural approaches, sociological approaches to studying family social discourse eating patterns aim to explain these patterns in relation to their socio-cultural contexts. Baker and Gibson (2014) emphasised that theoretical orientations for explaining collective family meal eating patterns have recommended cultural and symbolic expressions of food use, where eating patterns are understood to reflect systems of meaning constructed by people. Theoretical approaches that address the meanings of food and explain the reasons for family meal social interaction patterns are important, but require adequate practical and in-depth empirical study to provide a thorough explanation for family meal social interaction behaviours (Augoustinos et al, 2014).

Investigating social relations as the basis for understanding the importance of family meal social interaction patterns is a promising route for meeting this theoretical challenge (Argyle, 2013; Giddens, 2013; and Jaeger et al, 2013). Social relations as organised or structured social processes constitute the basis for understanding the importance of family meal social interaction behaviour (Parsons, 2013). The social context can be understood as the local configuration of social relations which are comprised of social structures such as class, race, and gender; institutional practices, collective and individual behaviour, and intersecting personal biographies (Fiske and Taylor, 2013). Fiske and Taylor reiterated that family eating patterns that are characteristic of different groups of people can be understood as being embedded in configurations of social relations and being shaped distinctively by them. Fiske and Taylor therefore, referenced the family social interaction patterns observed in a community of indigenous people situated on reserve lands in the Canadian province of Québec, which are reflective of the social relations underlying the political, economic and meaning systems of that place. Thompson (2013) emphasised that using social relations as a basis for understanding and explaining family meal social interaction patterns as social processes, accommodates both symbolic and material possibilities as well as cultural and material conditions. As a result, by examining family meal social interaction behaviour as social practice as professed by the various theorists provides a conceptual entry point for apprehending the underlying role of social relations, which connect people in the social world, and which generates family eating patterns (Fiske and Taylor, 2013; Parsons, 2013; Thompson, 2013).

Family meal social interaction is a communicative event bonded in time and space, delimited in its participants and governed by rules of interaction (Castells, 2013; and Haslett, 2013). Hartley (2013) noted that this family social interaction occupies a particular place on a continuum between mundane, day-to-day informal encounters at the dinner table to more formal public events that requires serious and significant discussions that borders on the welfare of the family. Cressey and Jones (2013); Forrester (2014); and Taylor (2014) argued that any occasion of face to face social interaction comes into existence through the selection and re-organisation of phenomenal elements, together with a degree of closure, however, fragile, that sets the occasion apart from other activities. The argument of family meal social interaction being delimited in its participants is questionable as it depends on the kind of 
family and degree of openness to accommodate more people. A number of researchers, including: Butler and Wilkinson (2013); Epp et al (2014); and Tye-Murray (2014), have suggested that, family participation and interaction at the dinner table is limited to only immediate members and other extended members are restricted. However, to get clarity into the argument raised by the theorists, a thorough study that investigates the degree of truism can be germane.

\section{Methodology:-}

This study was conducted in the urban settings of Sierra Leone using constructionist approach as families were asked to provide an in-depth view of their families' experiences when interacting socially at mealtimes. The study used a qualitative approach in detailing the behaviours of families. In effect, the study used multiple approaches in collecting data, including: semi-structured face to face interviews, observation, field notes, and archival analysis. The participants for the research were selected from 20 different Sierra Leonean families (husbands and wives) with different ethnic and cultural backgrounds. As a result, the study had a sample size of 40 interviewees. The sampling techniques used in collecting the data, include: snowballing, experiential and convenience sampling. Before conducting the primary data collection, a pilot study was carried out on four families (with a sample size of 8 interviewees) to assess the suitable of the interview protocol developed for the research. The data obtained from the pilot study were then coded and analysed to assess whether they conformed to the research questions and objectives. Upon confirm their compatibility with the research questions and objectives, the stage was set for the conduction of the primary data. The researcher ensured that each participant selected for the interview were willing and eager to participate and were also given the freedom to rescind their interest at any time, if they are uncomfortable to continue with the interview. To ascertain their appropriateness as interviewees, the researcher carried out thorough background checks on their ethnic, religious and marital statuses to ensure fair in the presentation of the data. This approach ensured that the same number of respondents is selected from the two religious groups (Muslims and Christians) and that the participants interviewed were married, which was a fundamental requirement for the research. The data was collected over a period of two months across the provincial headquarter towns of Sierra Leone. The data was analysed and transcribed using NVIVO 10 and thematic analysis. This approach helped in identifying the frequency with which certain issues or themes occurred in the primary data.

\section{Results and Analysis:-}

Analytically, this study categorised ethnicity into the following sub-groups, including: tribe; region of origin; cultural beliefs; and assumptions, which are individually discussed below:

Tribe:-

A tribe in this study refers to people belonging to the same social or familial groups with kinship networks and share a common language, beliefs, practices and values, and usually comes from the same region, including: city; community; village; or town.

\begin{tabular}{|l|l|}
\hline Q.5 & $\begin{array}{l}\text { In what ways does your tribe influence your family's meal social interaction behaviour at the } \\
\text { dinner table? }\end{array}$ \\
\cline { 2 - 3 } & $\begin{array}{l}\text { Muslim Females: } \\
\text { Themes in common were: identity } \\
\text { Differences were reflected in the following domains: cultural values; respect; gratifying parents; } \\
\text { food ethics }\end{array}$ \\
\cline { 2 - 2 } & $\begin{array}{l}\text { Christian Females: } \\
\text { Themes in common were: modernity; identity } \\
\text { Differences were reflected in the following domains: hierarchy; respect; food ethics; family unity; } \\
\text { sense of belonging }\end{array}$ \\
\cline { 2 - 2 } & $\begin{array}{l}\text { Muslim Males: } \\
\text { Themes in common were: respect; acceptance } \\
\text { Differences were reflected in the following areas: authority; family unity; food ethics }\end{array}$ \\
\cline { 2 - 2 } & $\begin{array}{l}\text { Christian Males: } \\
\text { Themes in common were: food ethics; respect } \\
\text { Differences were reflected in the following domain: tolerance; obedience; sharing; freedom of } \\
\text { expression; politeness }\end{array}$ \\
\hline $\begin{array}{l}\text { Observational } \\
\text { data }\end{array}$ & \begin{tabular}{l} 
No observation came up as relevant tribal factor(s) \\
\hline
\end{tabular} \\
\hline
\end{tabular}




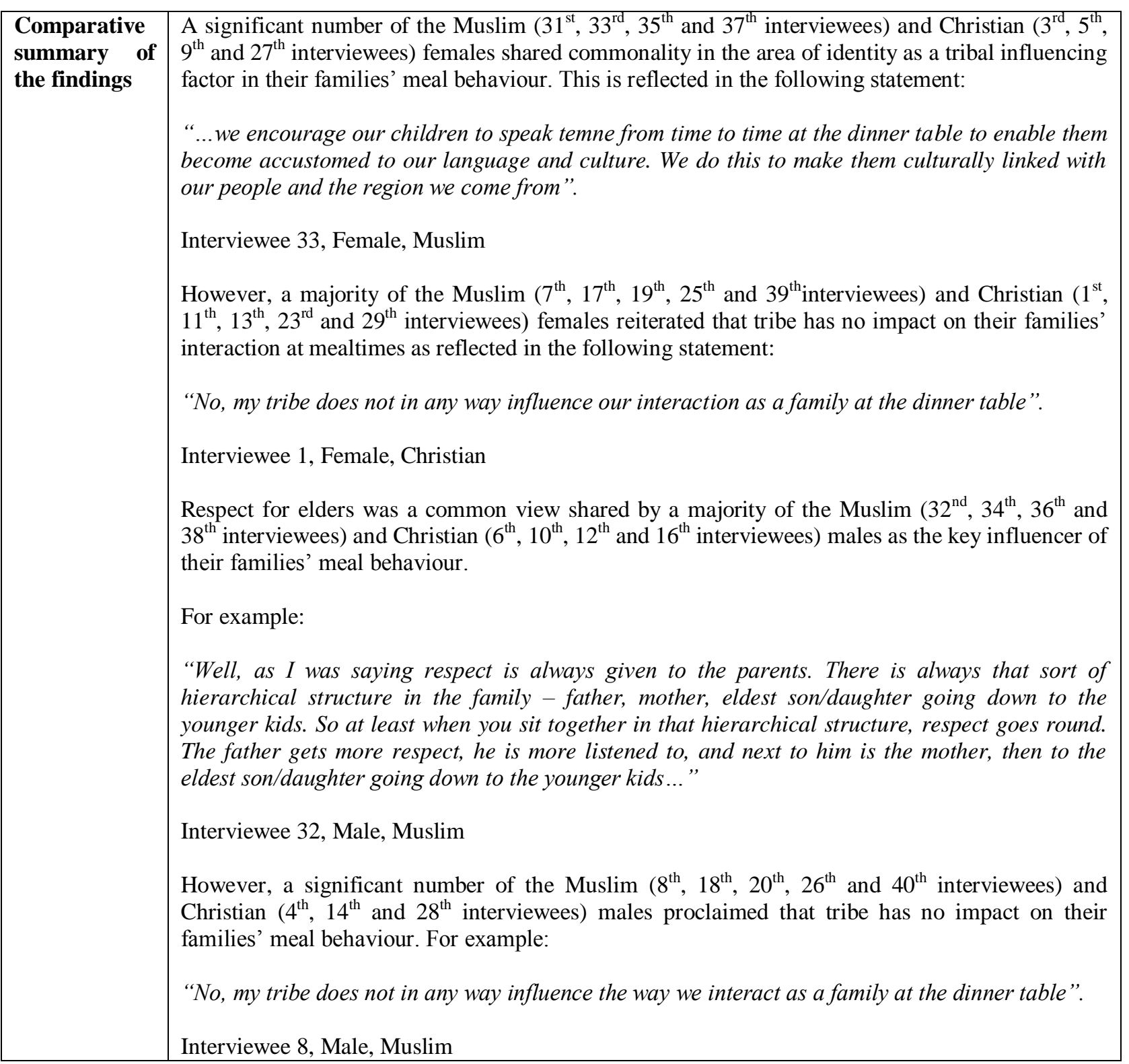

\section{Region of origin:-}

Region of origin in this study refers to the degree of customary influence or non-influence a family's birth place has on their current meal behaviour, including: food ethics; religious beliefs; affection; gender differentiation; hierarchy; and ethnic group.

\begin{tabular}{|l|l|}
\hline Q.6 & $\begin{array}{l}\text { In what ways does your region of origin influence the way your family interact at the dinner } \\
\text { table? }\end{array}$ \\
\cline { 2 - 3 } & $\begin{array}{l}\text { Muslim Females: } \\
\text { Themes in common were: respect; food ethics } \\
\text { Differences were reflected in the following domains: prayers; gender distinction; role definition; } \\
\text { dialect }\end{array}$ \\
\hline $\begin{array}{l}\text { Christian Females: } \\
\text { Themes in common were: respect } \\
\text { Differences were reflected in the following domains: cultural beliefs; gratifying parents; sharing; } \\
\text { dialect }\end{array}$ \\
\hline $\begin{array}{l}\text { Muslim Males: } \\
\text { Themes in common were: respect; hierarchy; gender distinction }\end{array}$ \\
\hline
\end{tabular}




\begin{tabular}{|c|c|}
\hline & Differences were reflected in the following areas: food ethics; prayers; family unity \\
\hline & $\begin{array}{l}\text { Christian Males: } \\
\text { Themes in common were: food ethics; sharing; respect } \\
\text { Differences were reflected in the following domain: modernity; family unity; cultural values; } \\
\text { family religious values }\end{array}$ \\
\hline $\begin{array}{l}\text { Observational } \\
\text { data }\end{array}$ & No observation was made on region of origin \\
\hline $\begin{array}{l}\text { Comparative } \\
\text { summary of } \\
\text { the findings }\end{array}$ & 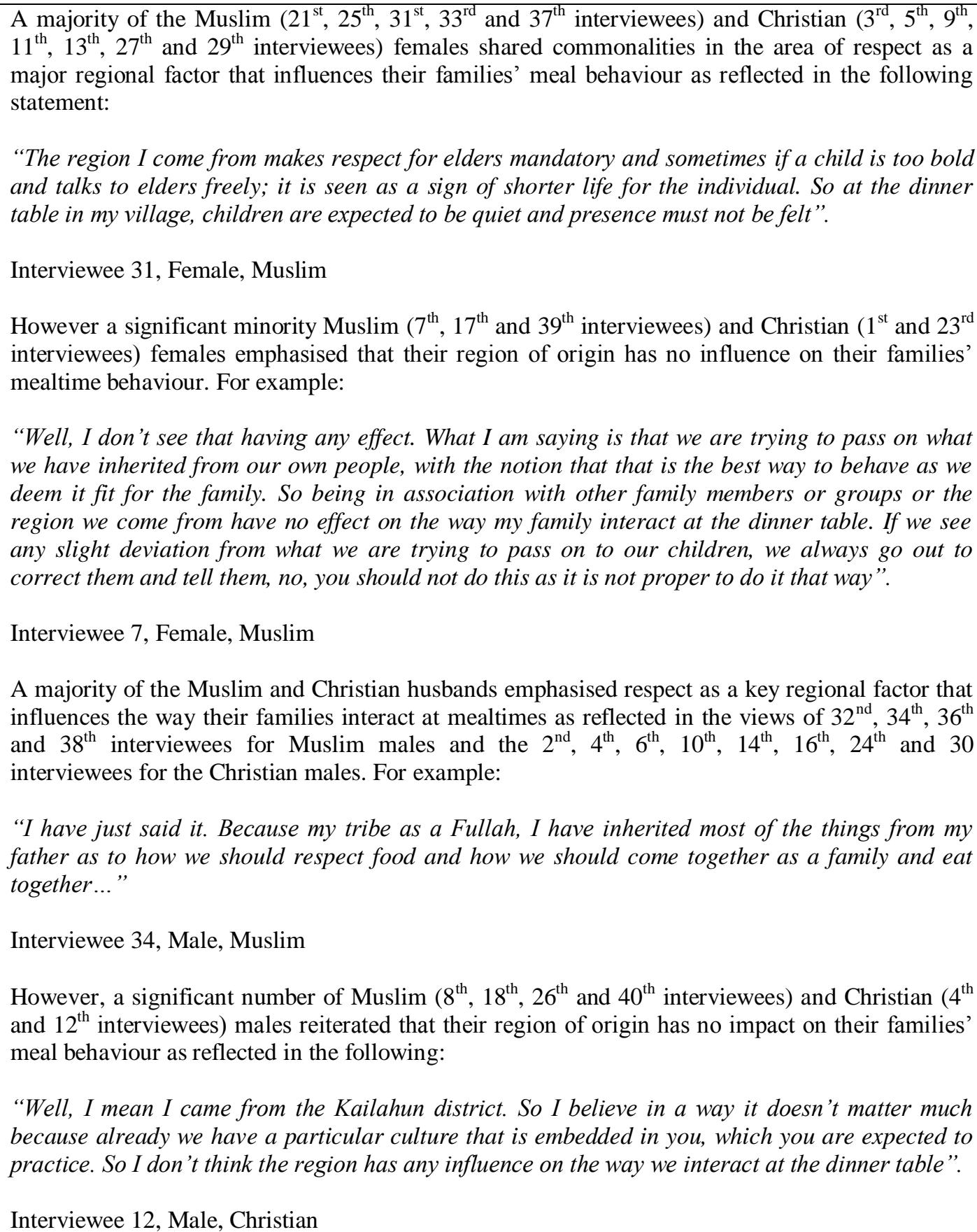 \\
\hline
\end{tabular}

\section{Cultural beliefs:-}

Cultural beliefs in this study are norms, standards and expectations held by families as convictions or set requirements for every member of the family at mealtimes, which are transmitted from one generation to another over a period of time. 


\begin{tabular}{|c|c|}
\hline \multirow[t]{5}{*}{ Q.7 } & $\begin{array}{l}\text { In what ways does your cultural belief influence your family's meal social interaction } \\
\text { behaviour? }\end{array}$ \\
\hline & $\begin{array}{l}\text { Muslim Females: } \\
\text { Themes in common were: respect; food type; food ethics } \\
\text { Differences were reflected in the following domains: gratifying parents; family norms/values; } \\
\text { family religious beliefs; control }\end{array}$ \\
\hline & $\begin{array}{l}\text { Christian Females: } \\
\text { Themes in common were: food ethics } \\
\text { Differences were reflected in the following domains: family unity; respect }\end{array}$ \\
\hline & $\begin{array}{l}\text { Muslim Males: } \\
\text { Themes in common were: respect; food ethics; food type } \\
\text { Differences were reflected in the following areas: hierarchy; prayer; family unity }\end{array}$ \\
\hline & $\begin{array}{l}\text { Christian Males: } \\
\text { Themes in common were: food ethics } \\
\text { Differences were reflected in the following domain: respect; modernity; sharing }\end{array}$ \\
\hline $\begin{array}{l}\text { Observational } \\
\text { data }\end{array}$ & $\begin{array}{l}\text { Before sitting at the dinner table, some families were observed washing their hands from a } \\
\text { common bowl. Prayer was also observed by a number of families and they were quiet throughout } \\
\text { the dinner. In some families, girls served the dinner, while the boys brought water to the dining } \\
\text { table. Hierarchy in terms of sitting position was observed. }\end{array}$ \\
\hline $\begin{array}{l}\text { Comparative } \\
\text { summary of } \\
\text { the findings }\end{array}$ & 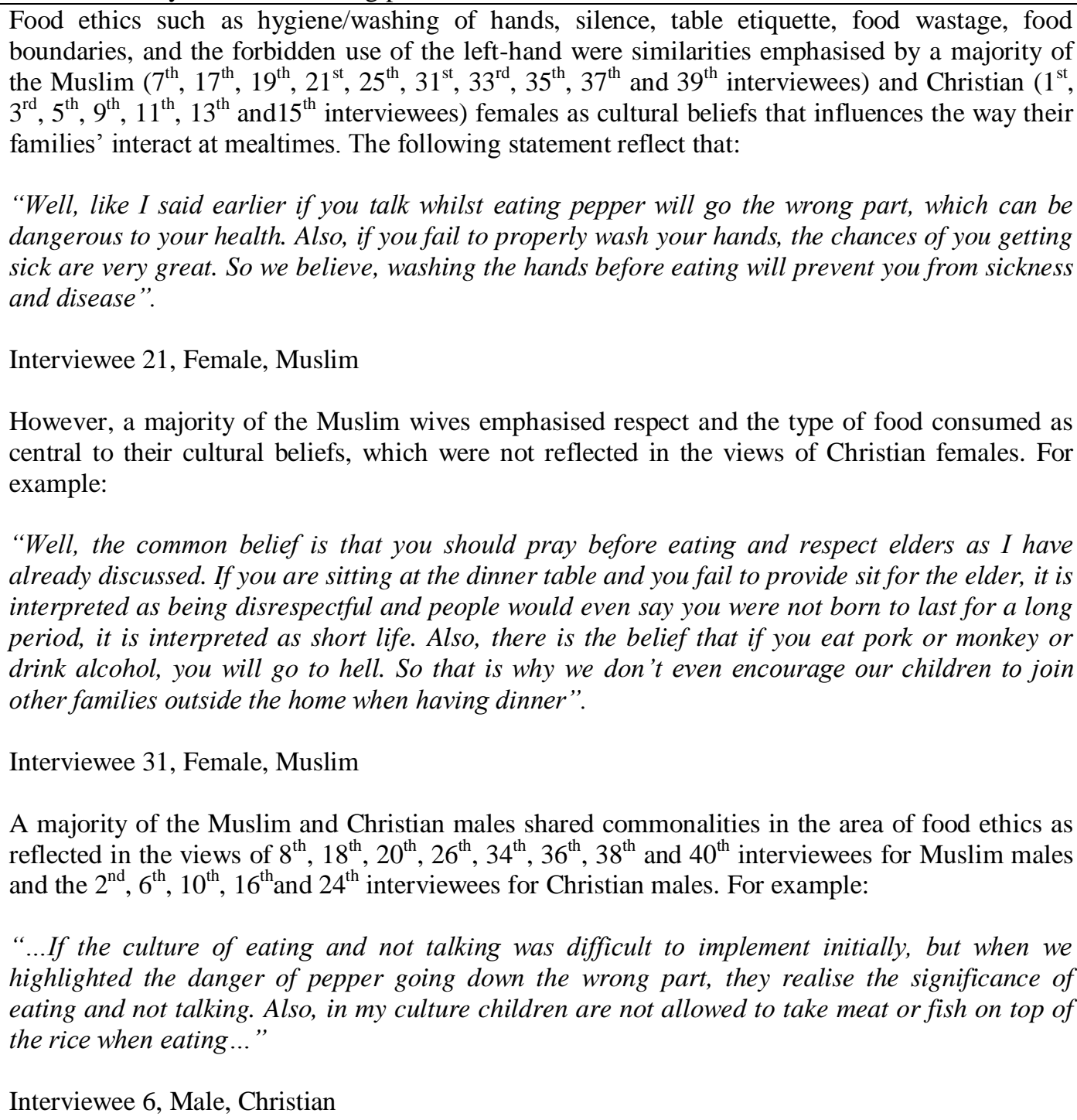 \\
\hline
\end{tabular}




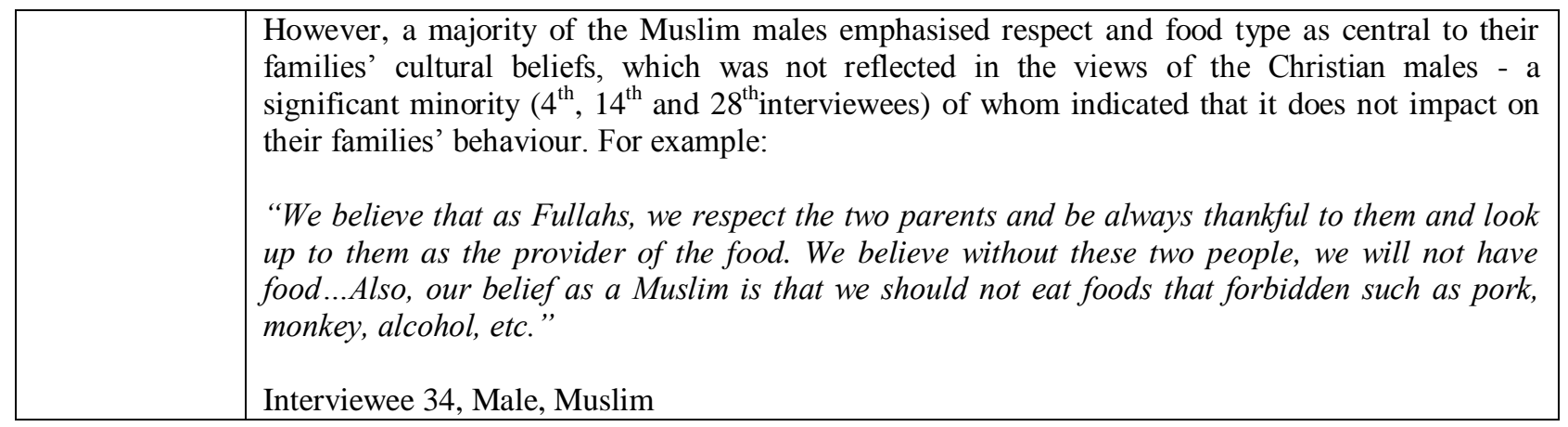

\section{Assumptions:-}

Assumptions in this study are the taken for granted views that are unexplained to members of the family at mealtimes, but are expected to be followed by every member of the family at mealtimes. They are unspoken and unwritten social norms.

\begin{tabular}{|c|c|}
\hline \multirow[t]{5}{*}{ Q.8 } & $\begin{array}{l}\text { What taken for granted practices (assumptions) influence the way your family } \\
\text { interact at the dinner table? }\end{array}$ \\
\hline & $\begin{array}{l}\text { Muslim Females: } \\
\text { Themes in common were: prayer; gratification; respect; God provider; food ethics } \\
\text { Differences were: reflected in the following domains: sense of responsibility; obedience; } \\
\text { family unity; moral education }\end{array}$ \\
\hline & $\begin{array}{l}\text { Christian Females: } \\
\text { Themes in common were: food ethics; prayers; respect; sense of responsibility } \\
\text { Differences were reflected in the following domains: affection; family unity; gratification; } \\
\text { family image }\end{array}$ \\
\hline & $\begin{array}{l}\text { Muslim Males: } \\
\text { Themes in common were: prayers; food ethics; respect } \\
\text { Differences were reflected in the following areas: God's protection; family cultural values; } \\
\text { family unity; hierarchy }\end{array}$ \\
\hline & $\begin{array}{l}\text { Christian Males: } \\
\text { Themes in common were: prayers; respect; food ethics } \\
\text { Differences were reflected in the following domain: family unity; conformity; humility }\end{array}$ \\
\hline $\begin{array}{l}\text { Observational } \\
\text { data }\end{array}$ & $\begin{array}{l}\text { In a number of families, girls knelt down when giving water to their fathers. Every member } \\
\text { of the family washed their hands before sitting at the dinner table. In some families, silence } \\
\text { was observed, prayers were conducted silently and the father was first served followed by } \\
\text { the eldest son. Hierarchy was observed. }\end{array}$ \\
\hline $\begin{array}{l}\text { Comparative } \\
\text { summary of the } \\
\text { findings }\end{array}$ & $\begin{array}{l}\text { Prayer, respect for elders and food ethics, including basic hygiene/washing hands; silence; } \\
\text { table etiquette; no food wastage; forbidden use of left-hand; and appreciation are } \\
\text { commonalities shared by a majority of Muslim }\left(7^{\text {th }}, 17^{\text {th }}, 19^{\text {th }}, 21^{\text {st }}, 25^{\text {th }}, 31^{\text {st }}, 33^{\text {rd }}, 35^{\text {th }}, 37^{\text {th }}\right. \\
\text { and } 39^{\text {th }} \text { interviewees) and Christian }\left(1^{\mathrm{st}}, 3^{\text {rd }}, 5^{\text {th }}, 9^{\text {th }}, 11^{\text {th }}, 13^{\text {th }}, 15^{\text {th }}, 23^{\text {rd }}, 27^{\text {th }} \text { and } 29^{\text {th }}\right. \\
\text { interviewees) females as taken for granted behaviours they expect from members of their } \\
\text { families at mealtimes. For example: } \\
\text { "When we start eating, my children know that they are not allowed to talk because if you } \\
\text { talk the food we get up your head. So after prayers, nobody is allowed to talk and we are } \\
\text { all required to concentrate on the food. After eating, the younger ones will clear the table. } \\
\text { This was the principle I met my parents implementing and I am doing the same to my } \\
\text { children to make them more responsible and respectful to their elders. The place I grew-up } \\
\text { in we all use to eat together and the younger ones are expected to clear the table, wash the } \\
\text { plates and pans, and sweep the floor". } \\
\text { Interviewee } 13 \text {, Female, Christian }\end{array}$ \\
\hline
\end{tabular}




\begin{abstract}
However, the findings also showed that there are differences between the two denominations as a majority of the Muslim females emphasised gratifying parents, including the assumption that God is the provider of the food the family eats, whilst a majority of the Christian females were more inclined to emphasise that the assumptive practices makes children more responsible. This is indicated by the following statement:

"...we should pray before eating, and we should pray after eating, we should say thank you to whoever cooked the food, and we thank god for the provision”.
\end{abstract}

Interviewee 15, Female, Christian

A majority of the Muslim $\left(18^{\text {th }}, 20^{\text {th }}, 22^{\text {nd }}, 26^{\text {th }}, 32^{\text {nd }}, 34^{\text {th }}, 36^{\text {th }}\right.$ and $38^{\text {th }}$ interviewees $)$ and Christian $\left(2^{\text {nd }}, 4^{\text {th }}, 6^{\text {th }}, 10^{\text {th }}, 12^{\text {th }}, 14^{\text {th }}, 16^{\text {th }}, 24^{\text {th }}, 28^{\text {th }}\right.$ and $30^{\text {th }}$ interviewees $)$ males expressed similar views with regards to prayers, food ethics and respect as key assumptive practices their families must observe at mealtimes as reflected in the following statement:

“...We normally pray before eating our dinner and I always ask my kids to pray, hold the dish when eating, wash your hand thoroughly before eating, you don't talk when eating, you don't take a portion of the food in front of your dad or an elder, you have to respect elders. For example, if we are all eating together from the same bowl and then you take portion of the food in front of me, it is translated as ill-mannered".

Interviewee 12, Male, Christian

\section{Discussion:-}

Discussion of the impact of ethnicity on families is categorised into tribes, region of origin, cultural beliefs and assumptions, each of the sub-factors are discussed in detailed below:

\section{The impact of tribe:-}

In highlighting tribe as an ethnic factor in their families' meal behaviour, a majority of Muslim females, Christian females and Muslim males, and a minority of Christian males emphasised that tribe has no impact on the way their families' interact at mealtimes. A minority of Muslim and Christian males emphasised respect for elders as fundamental to their families' meal behaviour. Despite these similarities, differences were evident as the results showed that whilst a minority of Christian females were emphatic about modernity as influencer on the way their families behave at mealtimes, a minority of Muslim males were more emphatic about acceptance, and a minority of Christian males emphasised food ethics as a symbolic influencer of the way their families interact at mealtimes. The results of the findings also showed that even within the same religion and gender groups, there are marked differences, including: cultural values; respect; gratifying parents; food ethics; hierarchy; and family unity. Other differences that emerged from the result of the study among families of the same religious and gender groups include: authority; tolerance; obedience; sharing; freedom of expression; and politeness. This suggests that a minority of the interviewees held both negative and positive views of the impact of tribe in their families' meal behaviour, and that the division in views could largely be due to modernity, civilisation and to the fact that the families are acculturating to urban or western style of living, and this trend is likely to continue in the future. The use of identity in this study as a tribal instrument is reflective of the views of Peštek and Činjarevic (2014); and Zeiders et al (2013), who suggested that tribal values are of particular relevance in explaining the identity of individuals, and that it can also be used as a discriminatory instrument and/or adherence to a group. Displaying its uniqueness and deviating from the generic views of Peštek and Činjarevic (2014); and Zeiders et al (2013), this study is the first to highlight the declining significance of tribe or at least supporting the acculturation perspective among families. The implication of this is that the degree of tribal influence and impact may vary from family to family, from social group to social group and from region to region, which may require further study to unravel the reasons for these differences and identify the true impact of tribe on families' meal social interaction behaviour. As a consequence, undertaking further study to determine the degree of tribal influences can provide a broader picture of its impacts on families. This study develops on previous ones and demonstrates the declining symbolism of tribe as influencer of families and highlights the gaps inherent in previous studies such as: the generic view that tribe 
influences' behaviour. These were the gaps this study sought to fill in order to strengthen the argument for future researchers.

\section{The impact of region of origin:-}

In discussing the interviewees' perspectives on region of origin as an ethnic factor, a majority of Muslim females, Christian females and Christian males, and a minority of Muslim males emphasised that respect as a regional factor is the most critical to their families' meal behaviour. However, a significant minority of Christian males emphasised food ethics and meal sharing, the Muslim females were more emphatic about food ethics, and the Muslim males emphasised gender distinction and hierarchy as fundamental regional influencers of the way their families behave at mealtimes. Despite no discriminatory issues or differences in the treatment of gender emphasised by families, it is indicative that males and females eat separately and the roles are also different as females are trained to prepare and serve food. The results of this study also showed that regional differences exists even between people of the same gender and religious background, including attitude to: prayers; role definition; dialect; cultural beliefs; gratifying parents; family unity; modernity; cultural values; and family religious values. This suggests that a majority of the interviewees have a positive view about their region of origin, while a significant minority held a negative perspective. This further suggests that despite the symbolism of acculturation or modernity in the lives of a reasonable number of families, a majority of them are still influenced by their regional background due to their concern of losing touch with their cultural lineage and ancestral background. This view is consistent with Rampton (2014), who identified region of origin and ethnic social groups as primarily linked to ethnicity. However, this study provides a deeper perspective about the impact of region of origin on families' meal behaviour in Sierra Leone by highlighting factors such as: respect; food ethics; hierarchy; gender distinction; and sharing as fundamental regional influencers of the way families behave at mealtimes as they help guide the upbringing of children and foster a sense of connectedness with where they come from. This implies that families' region of origin is fundamental to their way of life, and they keep tap with their regional values/linkage for fear of being ostracised by their own people and the broader impact such ostracisation may have on their families in the long-term. These regional factors are essentially the gaps this study sought to fill.

\section{The impact of cultural beliefs:-}

In evaluating the impact of cultural beliefs as a factor of ethnicity, a majority of Muslim females, Christian females, Muslim males and Christian males emphasised that food ethics such as hygiene/washing of hands, silence, table etiquette, no food wastage, observing food boundaries, and the forbidden use of the left-hand are fundamental to their families' meal behaviour. Despite these similarities, a majority of Muslim males and females emphasised respect for parents, and the type of food and drink consumed by their families as critical to their cultural beliefs at mealtimes; factors considered insignificant by Christian wives and husbands - a significant minority of whom indicated that cultural beliefs do not affect their families' social discourse at mealtimes. It is also implied from the results that a majority of Muslim females and males emphasised prayers as central to their families' meal behaviour. The results of the findings also show that there are differences between interviewees of the same religious and gender groups in terms of cultural beliefs, including: gratifying parents; family norms/values; family religious beliefs; control; family unity; hierarchy; modernity; and sharing. This suggests that a majority of the interviewees have a positive opinion of cultural beliefs as influencers of their families' meal behaviour, while a minority of the interviewees reiterated that cultural beliefs do not affect their families' meal behaviour. This further suggests that despite acculturation or modernity has an impact on families, but it is of a lesser extent as a majority of the respondents, even with urbanisation, are still influenced by their prior family cultural background. Blaydes and Grimmer (2013); Brice (2012); and Halpern (2013) posited that cultural beliefs are norms largely shared within ethnic groups with defined boundaries, which are consistent with the findings of this study. However, this study has been able to detail and specify in the Sierra Leonean context the different components of cultural beliefs such as food ethics, respect, the type of food consumed and prayers as influencers of families' meal behaviour, which was lacking in the findings of studies conducted by Blaydes and Grimmer (2013); Brice (2012); and Halpern (2013) . This implies that irrespective of the type of family background, differences in cultural beliefs are bound to emerge either due to cultural orientation, cultural upbringing, emigration/migration or religious orientation. This is because families'cultural beliefs are largely influenced by the ethics of the group they come from, and the groups they belong to, the religion they belong to and/or due to their movement from one geographic location of a country to another. This was the gap identified by the researcher and which this study sought to address, which presents a whole new discussion to the concept of cultural beliefsin families' meal social discourse behaviour. 


\section{The impact of assumptions:-}

In proclaiming the impact of assumptions or 'taken for granted behaviour' as an ethnic influencing factor, a majority of the interviewees (Muslim and Christian females, and Muslim and Christian males) posited that prayer, respect for elders and food ethics, including basic hygiene/washing hands; silence; table etiquette; no food wastage; forbidden use of left-hand; and appreciation were fundamental to their families' mealtime behaviour. These factors they claimed are unexplained, but known by each and every member of the family and are introduced as part of family socialisation. Despite these similarities, a majority of the Muslim females were more emphatic about the gratification of parents and God as the provider of the food the family eat, whist a majority of the Christian females were more emphatic about sense of responsibility as essential assumptive practices in their families' meal behaviour. No assumptive distinctions emerged between the Muslim and Christian males. The results also showed that there are differences in assumptive practices even between families of the same religious background and gender groups, including: obedience; family unity; moral education; affection; family image; God's protection; family cultural values; hierarchy; conformity; and humility. This suggests that a majority of the interviewees are largely influenced by assumptive practices, which are fundamental to their way of life and defines their families' meal behaviour, and that the symbolism of these practices are ingrained in the Sierra Leonean society. The results from families reflects the views of Bejanyan et al. (2014); and Devos and Vu (2014), who emphasised that ethnic traditionalists are held together primarily by assumptive emotional ties as a result of long history and that their children are socialised to internalise these cultural values. Despite the fact that this study is consistent with the conclusion of studies conducted by Bejanyan et al. (2014); and Devos and Vu (2014), which suggested a generic and broad view of assumptions, the findings of this study offers in-depth and specific assumptive practices, including: prayer, respect for elders and food ethics that influence Sierra Leonean families' meal behaviour - evidences that were lacking in studies conducted by prior researchers. This further implies that despite some of the negative consequences of assumption such as the non-use of the left hand at mealtimes, it is a proclaimed and accepted practice among people of various religious denominations as it defines their behaviour at mealtimes.

\section{Conclusion:-}

The results of the findings of this study highlight the significance of affection, gender differentiation, education and hierarchy in families' meal consumption behaviour. However, it was evident from the findings that failure to demonstrate emotional ties at mealtimes can have a debilitating effect on families' cohesiveness and display of common strength. This without doubt serves to strengthen the bond and unifies the family around a common goal. This is important because it can help foster oneness, happiness, unity and harmony within the family, which is essential for stability, progress and sustainability overtime when interacting socially at mealtimes. This affects families' meal behaviour by ensuring that every family member displays a show of concern for the others around the dinner table as well as exhibiting knowledge of their well-being. This show of affection is symbolic as it is the key determinant of prolonging family lineage and the stimulant for establishing continual bonding and contacts even when they families are disintegrated and separated into new ones. It is important to emphasise that despite the findings of this study are generally compatible with those of earlier researchers, they results do not support the notion that tribe is a key ethnic influencing factor, as a majority of families stated that its influence is inconsequential in their dealings with other family members. The implications of this conclusion are that families' display of affection can have a positive impact on the way they relate with each other, which can have a multiplier effect on the way they share meals and/or sympathise/empathise with other family members.

\section{Reference:-}

1. Abbott, A. (2014). The system of professions: An essay on the division of expert labour. University of Chicago Press.

2. Aboud, F. E., \& Spears B. C. (2013). Positive and negative intergroup contact among children and its effect on attitudes. Advances in intergroup contact, 176-199.

3. Abraham, A., Abdullah, I., Gberie, L., M'bayo, T., Cole, G., Blyden, N., \& Bangura, Y. (2013). The Paradoxes of History and Memory in Post-colonial Sierra Leone. S. Ojukutu-Macauley, \& I. Rashid (Eds.). Lexington Books.

4. Akinsulure-Smith, A. M., \& Smith, H. E. (2014). Toward Sustainable Family Policies in Sierra Leone: Developments and Recommendations. In Handbook of Family Policies Across the Globe, 1, pp. 15-29. Springer New York.

5. Alesina, A., \& Giuliano, P. (2013). Culture and institutions (No. w19750). National Bureau of Economic Research, Cambridge. 
6. Allen, J. D., Caspi, C., Yang, M., Leyva, B., Stoddard, A. M., Tamers, S., ...\& Sorensen, G. C. (2014). Pathways between acculturation and health behaviors among residents of low-income housing: The mediating role of social and contextual factors. Social Science \& Medicine, 123, 26-36.

7. Argyle, M. (2013). The social psychology of everyday life. Routledge.

8. Augoustinos, M., Walker, I., \&Donaghue, N. (2014). Social cognition: An integrated introduction. Sage.

9. Back, L. (2013). New Ethnicities and Urban Cult. Routledge.

10. Baker, S. R., \& Gibson, B. G. (2014). Social oral epidemi (olog) 2y where next: one small step or one giant leap?. Community dentistry and oral epidemiology, 42(6), 481-494.

11. Bartkowski, J. P., \& Shah, S. (2014). Religion and Gender Inequality. Religion and Inequality in America: Research and Theory on Religion's Role in Stratification, 40(2), 173.

12. Beattie, J. (2013). Other cultures: Aims, methods and achievements in social anthropology. Routledge.

13. Beh, L. S., \& Kennan, W. R. (2013). Leadership in the East: A Social Capital Perspective. Culture and Gender in Leadership: Perspectives from the Middle East and Asia, 45, 9.

14. Bejanyan, K., Marshall, T. C., \&Ferenczi, N. (2014). Romantic Ideals, Mate Preferences, and Anticipation of Future Difficulties in Marital Life: A comparative study of young adults in India and America. Name: Frontiers in Psychology, 5, 1355.

15. Biziouras, N. (2014). The Political Economy of Ethnic Conflict in Sri Lanka: Economic Liberalization, Mobilizational Resources, and Ethnic Collective Action. Routledge.

16. Black, C. (2013). It will never happen to me: Growing up with addiction as youngsters, adolescents, adults. Hazelden Publishing.

17. Black, C. (2013). Straight talk from Claudia Black: what recovering parents should tell their kids about drugs and alcohol.Hazelden Publishing.

18. Blaydes, L., \& Grimmer, J. (2013). Political Cultures: Exploring the Long-Run Determinants of Values Transmission. In Annual Meeting of the International Political Economy Society, Claremont Graduate School, Claremont, $C A$.

19. Bornstein, M. H., \& Bradley, R. H. (Eds.). (2014). Socioeconomic status, parenting, and child development. Routledge.

20. Brice, W. D. (2012). The effects of ethnic culture on managerial attitudes and practices: A survey in Hong Kong, Taiwan and China. International Journal of Management, 29(1), 267.

21. Brown, J. D. (2014). Self-esteem and self-evaluation: Feeling is believing. Psychological perspectives on the self, 4, 27-58.

22. Butler, C. W., \& Wilkinson, R. (2013). Mobilising recipiency: Child participation and 'rights to speak'in multiparty family interaction. Journal of Pragmatics, 50(1), 37-51.

23. Castells, M. (2013). Communication power. Oxford University Press.

24. Cawelti, J. G. (2014). Adventure, mystery, and romance: Formula stories as art and popular culture. University of Chicago Press.

25. Chang, J. (2014). The interplay between collectivism and social support processes among Asian and Latino American college students. Asian American Journal of Psychology, 6(1), 4.

26. Chen, H. (2013). Effects of Perceived Individualism-Collectivism and Self-Consciousness on the SelfDisclosure in Social Networking Sites.Asian American Journal of Psychology, 1, 5-6

27. Cohen, A. P. (2013). Symbolic construction of community. Routledge.

28. Cohen, A. P. (2013). Symbolic construction of community. Routledge.

29. Cooper, P., \&Cefai, C. (2013). Understanding and Supporting Students with Social, Emotional and Behavioural Difficulties: A Practical Guide for Staff in Schools, Routledge

30. Cressey, P., \& Jones, B. (Eds.). (2013). Work and employment in Europe: a new convergence?. Routledge.

31. De Mooij, M. (2013). Global marketing and advertising: Understanding cultural paradoxes. Sage Publications.

32. Des Rosiers, S. E., Schwartz, S. J., Zamboanga, B. L., Ham, L. S., \& Huang, S. (2013). A Cultural and Social Cognitive Model of Differences in Acculturation Orientations, Alcohol Expectancies, and Alcohol-Related Risk Behaviours Among Hispanic College Students. Journal of clinicalpsychology, 69(4), 319-340.

33. Devos, T., \& Vu, T. (2014). Implicitmulticulturalidentities. [Oxford] Handbook of Multicultural Identity, 227.

34. Diller, J. (2014). Cultural diversity: A primer for the human services. Cengage Learning.

35. Dinnerstein, L., \&Reimers, D. M. (2013). Ethnic Americans: Immigration and American Society. Columbia University Press.

36. Epp, A. M., Schau, H. J., \& Price, L. L. (2014). The Role of Brands and Mediating Technologies in Assembling Long-Distance Family Practices. Journal of Marketing, 78(3), 81-101. 
37. Fischer-Neumann, M. (2014). Immigrants' Ethnic Identification and Political Involvement in the Face of Discrimination: A Longitudinal Study of the German Case. Journal of Ethnic and Migration Studies, 40(3), 339-362.

38. Fiske, S. T., \& Taylor, S. E. (2013). Social cognition: From brains to culture. Sage.

39. Fitzsimmons, S. R., \& Stamper, C. L. (2014). How societal culture influences friction in the employeeorganization relationship. Human Resource Management Review, 24(1), 80-94.

40. Forrester, M. A. (2014). Early Social Interaction: A Case Comparison of Developmental Pragmatics and Psychoanalytic Theory. Cambridge University Press.

41. Gaertner, S. L., \& Dovidio, J. F. (2014). Reducing intergroup bias: The common in-group identity model. Psychology Press.

42. Gaines Jr, S. O. (2014). Culture, ethnicity, and personal relationship processes. Routledge.

43. Giddens, A. (2013). The transformation of intimacy: Sexuality, love and eroticism in modern societies. John Wiley \& Sons.

44. Glennerster, R., Miguel, E., \& Rothenberg, A. D. (2013). Collective action in diverse Sierra Leone communities. The Economic Journal, 123(568), 285-316.

45. Goar, C., Sell, J., Manago, B., Melero, C., \&Reidinger, B. (2013). Race and Ethnic Composition of Groups: Experimental Investigations. Advances in Group Processes, 30, 47-75.

46. Greenfield, P. M., \& Quiroz, B. (2013). Context and culture in the socialization and development of personal achievement values: Comparing Latino immigrant families, European American families, and elementary school teachers. Journal of Applied Developmental Psychology, 34(2), 108-118.

47. Guerrero, L., \&Posthuma, R. A. (2014). Perceptions and behaviours of Hispanic workers: a review. Journal of Managerial Psychology, 29(6), 3-3.

48. Hall, E. (1976) Beyond culture. Garden city, NY: Anchor Books

49. Halpern, D. F. (2013). Sex differences in cognitive abilities. Psychology press.

50. Han, M., \& Pong, H. (2015). Mental Health Help-Seeking Behaviours Among Asian American Community College Students: The Effect of Stigma, Cultural Barriers, and Acculturation. Journal of College Student Development, 56(1), 1-14.

51. Hansen, K. V. (2013). Encounter on the Great Plains: Scandinavian Settlers and the Dispossession of Dakota Indians, 1890-1930. Oxford University Press.

52. Hartley, J. (2013). Understanding news. Routledge.

53. Haslett, B. B. (2013). Communication: Strategic action in context. Routledge.

54. Häuberer, J., \&Tatarko, A. (2014). Network Composition, Individual Social Capital And Culture: Comparing Traditional And Post-Modernized Ethnic Groups. Higher School of Economics Research Paper No. WP BRP, 38 .

55. Herzfeld, M. (2014). Cultural intimacy: Social poetics in the nation-state. Routledge.

56. Hildebrand, D., DeMotta, Y., Sen, S., \&Kongsompong, K. (2013). In-Group and Out-Group Influences on the Consumption Behaviour of Minority Groups: The Case of Gay Men. Journal of Public Policy \& Marketing, 32(special issue), 70-78.

57. Ho, P. C., \& Johnson, M. H. (2013). Behaviours and beliefs about pain and treatment among Chinese immigrants and New Zealand Europeans. The New Zealand Medical Journal, 126(1370), 30-40.

58. Hofstede, G. (2001). Culture's consequences: Comparing values, behaviours, institutions, and organizations across nations (2nd ed.). Thousand Oaks, CA: Sage Publications.

59. Hofstede, G. (2003) Culture's consequences: Comparing values, behaviours, institutions and organisations across nations, $2^{\text {nd }}$ Edition. London, McGraw Hill.

60. Inkeles, A. (2013). Exploring individual modernity. Columbia University Press.

61. Jaeger, C. C., Webler, T., Rosa, E. A., \&Renn, O. (2013). Risk, uncertainty and rational action. Routledge.

62. Jirachiefpattana, W. (2014). Exploring the effect of meta-individual values on management of software development using Schwartz's model: A case of Thai IT professionals. In Computer Science and Information Technology (CSIT), 5th International Conference, pp. 162-168.

63. Kozhevnikov, M., Evans, C., \&Kosslyn, S. M. (2014). Cognitive Style as Environmentally Sensitive Individual Differences in Cognition A Modern Synthesis and Applications in Education, Business, and Management. Psychological Science in the Public Interest, 15(1), 3-33.

64. Kuczynski, L., \&Knafo, A. (2013). Innovation and continuity in socialization, internalization and acculturation. Handbook of moral development, 2, 93-112. 
65. Kuo, B. C. (2014). Coping, acculturation, and psychological adaptation among migrants: a theoretical and empirical review and synthesis of the literature. Health Psychology and Behavioural Medicine: an Open Access Journal, 2(1), 16-33.

66. Kuper, A. (Ed.). (2013). The social science encyclopaedia. Routledge.

67. Kwek, A., Wang, Y., \& Weaver, D. B. (2014). Retail tours in China for overseas Chinese: Soft power or hard sell?.Annals of Tourism Research, 44, 36-52.

68. Letseka, M. M. (2013). Understanding of African philosophy through philosophy for children (P4C). Mediterranean Journal of Social Sciences, 4(14), 745.

69. Little, K. (2013). Mende Of Sierra Leone Ils 65. Routledge.

70. Lopez-Class, M., Castro, F. G., \& Ramirez, A. G. (2011). Conceptions of acculturation: A review and statement of critical issues. Social Science and Medicine, 72, 1555-1562.

71. Lorenzo-Blanco, E. I., \& Cortina, L. M. (2013). Latino/a depression and smoking: An analysis through the lenses of culture, gender, and ethnicity. American journal of community psychology, 51(3-4), 332-346.

72. Lu, L. C., Chang, H. H., \& Yu, S. T. (2013). Online shoppers' perceptions of e-retailers' ethics, cultural orientation, and loyalty: an exploratory study in Taiwan. Internet Research, 23(1), 47-68.

73. Marshall, R., Huan, T. C. T., Xu, Y., \& Nam, I. (2011). Extending prospect theory cross-culturally by examining switching behaviour in consumer and business-to-business contexts. Journal of Business Research, 64(8), 871-878.

74. Marsiglia, F. F., Nagoshi, J. L., Parsai, M., Booth, J. M., \& Castro, F. G. (2014). The parent-child acculturation gap, parental monitoring, and substance use in Mexican heritage adolescents in Mexican neighbourhoods of the Southwest US. Journal of Community Psychology, 42(5), 530-543.

75. McFerson, H. M. (2013). Women and Post-Conflict Society in Sierra Leone. Journal of International Women's Studies, 13(1), 46-67.

76. Millan, E., \& Reynolds, J. (2014). Self-construals, symbolic and hedonic preferences, and actual purchase behavior. Journal of Retailing and Consumer Services, 21(4), 550-560.

77. Miller, D., \& Ali, S. (2014). Testing the national identity argument. European Political Science Review, 6(02), 237-259.

78. Million, D. (2013). Therapeutic nations: Healing in an age of indigenous human rights. University of Arizona Press.

79. Misztal, B. (2013). Trust in modern societies: The search for the bases of social order. John Wiley \& Sons.

80. Moran, R. T., Abramson, N. R., \& Moran, S. V. (2014). Managing cultural differences. Routledge.

81. Muk, A., Chung, C., \& Kim, J. (2014). A Cross-National Study of the Influence of Individualism and Collectivism on Liking Brand Pages. Journal of International Consumer Marketing, 26(2), 122-137.

82. Nash, R. F. (2014). Wilderness and the American mind. Yale University Press.

83. Neal, S., Bennett, K., Cochrane, A., \& Mohan, G. (2013). Living multiculture: understanding the new spatial and social relations of ethnicity and multiculture in England. Environment and Planning C: Government and Policy, 31(2), 308-323.

84. Oh, H., Yang, L. H., Anglin, D. M., \&DeVylder, J. E. (2014). Perceived discrimination and psychotic experiences across multiple ethnic groups in the United States. Schizophrenia research, 157(1), 259-265.

85. Oh, J. H., Kim, H. S., \& Lee, J. H. (2014). Asian Cultural Collectivism, Acculturation, and Life Satisfaction among Ethnic Asian Brides in South Korea. Asian Women, 30(3), 23-56.

86. Okamura, K. H., Ebesutani, C., Bloom, R., Higa-McMillan, C. K., Nakamura, B. J., \&Chorpita, B. F. (2010). Differences in Internalizing Symptoms Across Specific Ethnic Minority Groups: An Analysis Across Chinese American, Filipino American, Japanese American, Native Hawaiian, and White Youth. Journal of Child and Family Studies, 1-14, Springer International Publishing.

87. Parker, A. G., \&Grinter, R. E. (2014). Collectivistic health promotion tools: Accounting for the relationship between culture, food and nutrition. International Journal of Human-Computer Studies, 72(2), 185-206.

88. Parker, A. G., \&Grinter, R. E. (2014). Collectivistic health promotion tools: Accounting for the relationship between culture, food and nutrition. International Journal of Human-Computer Studies, 72(2), 185-206.

89. Parsons, T. (2013). Social system. Routledge.

90. Parsons, T. (2013). Social system. Routledge.

91. Peštek, A., \&Činjarević, M. (2014). Tourist perceived image of local cuisine: the case of Bosnian food culture. British Food Journal, 116(11), 10

92. Peterka-Benton, D., \& Benton, B. (2014). Effects of Cultural Collectivism on Terrorism Favorability. Journal of Applied Security Research, 9(1), 17-40. 
93. Pound, P., \& Campbell, R. (2014). Exploring the feasibility of theory synthesis: a worked example in the field of health related risk-taking. Social science \& medicine, 124, 57-65.

94. Qin, D. B., Saltarelli, A., Rana, M., Bates, L., Lee, J. A., \& Johnson, D. J. (2014). "My Culture Helps Me Make Good Decisions" Cultural Adaptation of Sudanese Refugee Emerging Adults. Journal of Adolescent Research, 30(2), 213-243.

95. Quarmby, T., \&Dagkas, S. (2013). Informal mealtime pedagogies: exploring the influence of family structure on young people's healthy eating dispositions. Sport, Education and Society, 20(3), 323-339.

96. Rampton, B. (2014). Crossings: Language and ethnicity among adolescents. Routledge.

97. Rebhun, U. (2014). Immigrant Acculturation and Transnationalism: Israelis in the United States and Europe Compared. Journal for the Scientific Study of Religion, 53(3), 613-635.

98. Renteln, A. D. (2013). International human rights: universalism versus relativism. Quid Pro Books.

99. Reykowski, J. (2012). Collectivism and individualism as dimensions of social change. In Individualism and collectivism: Theory, method, and applications, ed. U. Kim, C. Triandis, C. Kagitcibasi, and S.C. Choi, 276-92. Thousand Oaks, CA: Sage.

100.Robinson, T. R. J. A. (2013). The Chiefdoms of Sierra Leone, Cambriidge.

101.Sauer, J. J. (2015). Resilience Theory and Inevitable Change: Che Agency, Identity, and Strategic Reorganization. In The Archaeology and Ethnohistory of Araucanian Resilience (pp. 21-45). Springer International Publishing.

102.Schapper, A. (2013). From the global to the local: how international rights reach Bangladesh's children. Routledge.

103.Schlenker, A. (2014). Cosmopolitan Transnationals? The impact of Transnational Status on Cosmopolitanism. The impact of Transnational Status on Cosmopolitanism, 27 (1): 25-51

104.Schommer-Aikins, M., \& Easter, M. (2014). Cultural values at the individual level and the malleability of ways of knowing. Educational Psychology, 34(2), 171-184.

105.Schutte, H. and Ciarlante, D. (1998) "Consumer behaviour in Asia", International marketing series, Macmillan press limited, Houndmills/London

106. Schwartz, H. (2013). The culture of the copy: Striking likenesses, unreasonable facsimiles. MIT Press.

107.Schwartz, S. I , Unger, Zamboanga, \& Szapocznik, J (2010). Rethinking the concept of acculturation: Implications for theory and research. American Psychologist, 4, 237-251.

108.Serenari, C., Bosak, K., \&Attarian, A. (2013). Cross-cultural efficacy of American low-impact programs: A comparison between Garhwal guide beliefs on environmental behaviour and American outdoor travel norms. Tourism Management, 34, 50-60.

109.Smith, P. B., Fischer, R., Vignoles, V. L., \& Bond, M. H. (2013). Understanding social psychology across cultures: Engaging with others in a changing world. SAGE.

110.Stayman, D. M., \& Deshpande, R. (1989). Situational ethnicity and consumer behavior. Journal of Consumer Research, 16(3), 361-371.

111.Tal, D. (Ed.). (2013). Israeli Identity: Between Orient and Occident: Between Orient and Occident. Routledge.

112.Taylor, M. (2014). The Chinese State, Oil and Energy Security. Palgrave Macmillan.

113.Thompson, J. B. (2013). Ideology and modern culture: Critical social theory in the era of mass communication. John Wiley \& Sons.

114.Trompenaars, F. (1993) Rising waves of culture, London: Economist Books

115.Trovão, S. (2014). Comparing Transnational and Local Influences on Immigrant Transnational Families of African and Asian Origin in Portugal. Journal of Family Issues, 1(25), 25-26

116.Tye-Murray, N. (2014). Foundations of aural rehabilitation: Children, adults, and their family members. Cengage learning.

117.Umaña-Taylor, A. J., Quintana, S. M., Lee, R. M., Cross, W. E., Rivas-Drake, D., Schwartz, S. J., ...\& Seaton, E. (2014). Ethnic and Racial Identity During Adolescence and Into Young Adulthood: An Integrated Conceptualization. Child development, 85(1), 21-39.

118.Usunier, J.C. and Lee, J.A. (2009) Marketing Across cultures, 5th edition - Pearson education Limited.

119.Utami, H. D. (2014). Consumer BehaviorToward Goat Milk and Its Processed Products in Malang, Indonesia. Journal of International Food \& Agribusiness Marketing, 26(1), 1-12.

120.Vargas, J. H., \&Kemmelmeier, M. (2013). Ethnicity and contemporary American culture a meta-analytic investigation of horizontal-vertical individualism-collectivism. Journal of Cross-Cultural Psychology, 44(2), 195-222.

121.Vargas, N. (2013). Off white: colour-blind ideology at the margins of whiteness. Ethnic and Racial Studies, 37(13), 2281-2302. 
122.Walls, J. L., \&Triandis, H. C. (2014). Universal truths: can universally held cultural values inform the modern corporation?. Cross Cultural Management: An International Journal, 21(3), 345-356.

123.Wien, A. H., \& Olsen, S. O. (2014). Understanding the Relationship between Individualism and Word of Mouth: A Self-Enhancement Explanation. Psychology \& Marketing, 31(6), 416-425.

124.Yamaguchi, A. (2013). Influences of Social Capital on Health and Well-Being from Qualitative Approach. Global journal of health science, 5(5), p153.

125.Yuan, L. (2013). Traditional Chinese Thinking on HRM Practices: Heritage and Transformation in China. Palgrave Macmillan.

126.Zakaria, N., \&Yusof, S. A. M. (2014). Can We Count on You at a Distance? The Impact of Culture on Formation of Swift Trust Within Global Virtual Teams. In Leading Global Teams (pp. 253-268). Springer New York.

127.Zamboanga, B. L., Schwartz, S. J., Jarvis, L. H., \& Van Tyne, K. (2009). Acculturation and substance use among Hispanic early adolescents: Investigating the mediating roles of acculturative stress and self-esteem. The journal of primary prevention, 30(3-4), 315-333.

128.Zeiders, K. H., Umaña-Taylor, A. J., \&Derlan, C. L. (2013). Trajectories of depressive symptoms and selfesteem in Latino youths: Examining the role of gender and perceived discrimination. Developmental psychology, 49(5), 951.

129.Zhang, T., \& Zhao, X. (2013). Do Kinship Networks Strengthen Private Property? Evidence from Rural China. Journal of Empirical Legal Studies, 11(3), 505-540. 